University at Albany, State University of New York

Scholars Archive

University Libraries Faculty Scholarship

University Libraries

$7-2013$

\title{
Tag, You're It: Enhancing Access to Graphic Novels
}

Wendy L. West

University at Albany, State University of New York, wwest@albany.edu

Follow this and additional works at: https://scholarsarchive.library.albany.edu/ulib_fac_scholar

Part of the Cataloging and Metadata Commons

\section{Recommended Citation}

West, Wendy L., "Tag, You're It: Enhancing Access to Graphic Novels" (2013). University Libraries Faculty Scholarship. 45.

https://scholarsarchive.library.albany.edu/ulib_fac_scholar/45

This Article is brought to you for free and open access by the University Libraries at Scholars Archive. It has been accepted for inclusion in University Libraries Faculty Scholarship by an authorized administrator of Scholars Archive. For more information, please contact scholarsarchive@albany.edu. 


\section{PROJECT MUSE}

\section{Tag, You're It: Enhancing Access to Graphic Novels}

Wendy West

portal: Libraries and the Academy, Volume 13, Number 3, July 2013, pp. 301-324 (Article)

Published by The Johns Hopkins University Press

DOI: 10.1353/pla.2013.0023

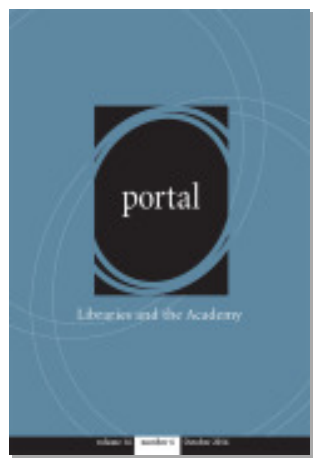

$\Rightarrow$ For additional information about this article http://muse.jhu.edu/journals/pla/summary/v013/13.3.west.html 


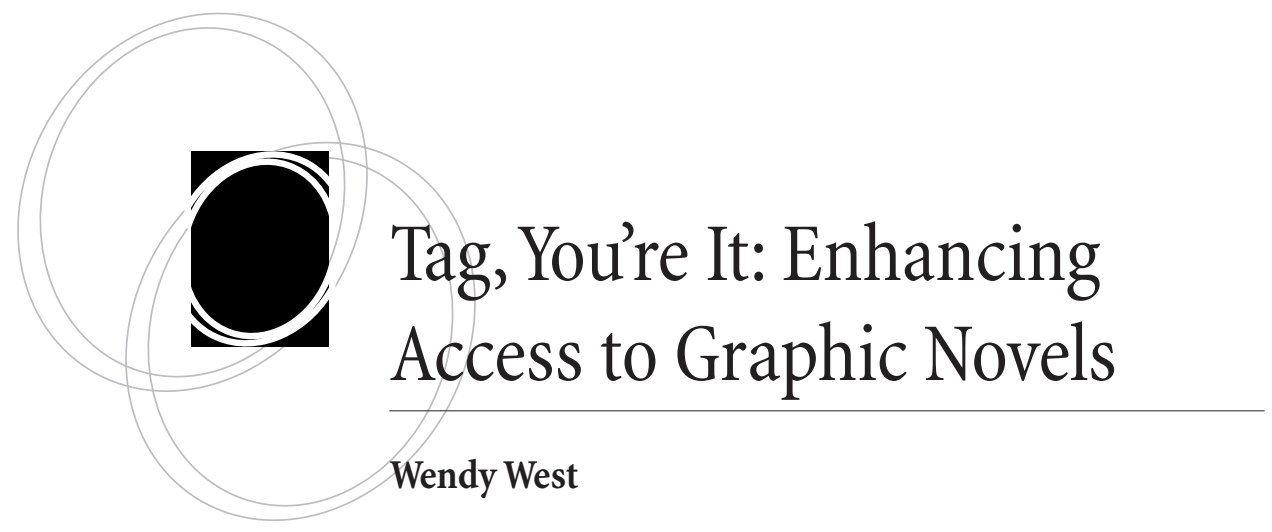

abstract: Current users of academic libraries are avid readers of graphic novels. These thoughtprovoking materials are used for leisure reading, in instruction, and for research purposes. Libraries need to take care in providing access to these resources. This study analyzed the cataloging practices and social tagging of a specific list of graphic novel titles in the academic libraries of the Association of Research Libraries (ARL). Results found that of the 668 graphic novel records 68 (10.17 percent) used the genre heading "graphic novel" and 99 (14.8 percent) were tagged. This limited access could be improved by using social tagging and genre heading.

\section{Introduction}

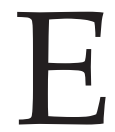

ach year academic libraries acquire materials to build and enhance their collections. These resources support an institution's curriculum; its faculty and student research activities; and users' leisure reading interests. For patrons to benefit from these materials, the sources need to be easily identifiable for efficient access so that users can locate them. A great deal of staff time and effort goes into the best methods for ensuring accessibility of library resources. For many years traditional cataloging practices have made this endeavor possible, especially with commonly acquired materials, such as books, journals, and videos. Over the last decade and a half, graphic novels have emerged as a new medium for users to read and appreciate. ${ }^{1}$ Graphic novels have become quite popular in public as well as academic libraries. Yet accessing graphic novels is not as straightforward a process as other resources for many reasons, including cataloging. Some libraries are employing social tagging options to enrich access possibilities. To determine cataloging and social tagging patterns of graphic novels this study was initiated. This research explored graphic novels in academic library collections with a specific focus on social tagging and cataloging practices.

Materials with unique publication formats, such as graphic novels, can be difficult to access via online catalogs and other library applications due to cataloging and clas- 
sification challenges. Libraries continue to struggle with the best presentation of that metadata for ease of access. Bibliographic records created by catalogers are the foundation of the traditional catalog, and now discovery tools provide another opportunity for access. In the pursuit of making data more accessible and provide functionality in a world that thrives on social applications, it is important not only to create, but to enrich the metadata placed in records. Simply put, library discovery tools and catalogs cannot retrieve data that does not exist within bibliographic records. At present, many libraries are attempting to implement innovative approaches to access library materials through the use of social media applications. Academic libraries are in the unique position to maximize access to library materials through social tagging. Since the newest generation of library users is accustomed to and fluent with Web 2.0 technologies, they have the capability to add and augment library records through a library's next generation

The tagging activities performed by specialized and knowledgeable individuals would be an excellent addition to augment the access provided in bibliographic records. catalog or discovery layer. Academic libraries can further increase access by encouraging user tagging in their local communities. In addition, many libraries have users who are experts in a range of disciplines and engage in different areas of scholarly inquiry and research. The tagging activities performed by specialized and knowledgeable individuals would be

an excellent addition to augment the access provided in bibliographic records.

In theory, the idea of social tags supplementing subject and genre headings is an interesting concept. End users would be able to search for materials or resources using terms from both a structured, hierarchal system (for example, Library of Congress Subject Headings), as well as by using natural language terms (for example, social tagging terminology). Much of the prior research focusing on academic libraries' social tagging practices explored relationships with the use of LibraryThing as a social tagging mechanism. ${ }^{2}$ LibraryThing is a service that enables individuals and organizations to catalog their resources and share that metadata. LibraryThing gets its metadata (social tags) from a variety of commercial sources and library catalogs. ${ }^{3}$ An affiliated resource, LibraryThing for Libraries (LTFL), provides the basic LibraryThing options as well as refined features providing customization and value-added materials, such as reviews. This current research study explored social tagging activities and cataloging practices with a focus on graphic novels.

\section{Literature Review}

\section{Graphic Novels}

There is a wide array of definitions for graphic novels, and as noted by Amanda StegallArmour, defining this term is a "slippery slope" for librarians when working with readers who range from graphic novel novices to aficionados. ${ }^{4}$ Catherine Labio contends that the phrase is misleading and detracts from the genre. ${ }^{5}$ Eddie Campbell wrote that-" confusion reigns" defining the graphic novel, with four different ways to do so: as a format, 
as a comic book, as a comic book written in a prose style, or one written with a higher ambition. ${ }^{6}$ In the United States, the term graphic novel was popularized by Will Eisner in 1978, when he placed the term on the cover of the paperback edition of A Contract with God and Other Tenement Stories. ${ }^{7}$ The Oxford English Dictionary defines a graphic novel within the "graphic" entry as "a full-length (esp. science fiction or fantasy) story published as a book in a comic-strip format." ${ }^{8}$ Sid Jacobson defined graphic novels as "fiction intended for adults in comic format." ${ }^{9}$ In 2003, Francesca Goldsmith connected the literature aspects of graphic novels and wrote:

Developed plotlines, complex characters, distinctive narrative stylistics, and rhetorical devices such as irony and symbolism are requisites for books we recognize as "literary," whether we are talking about fiction or about fact. Certainly, what's considered "literature" is much more than just a recapitulation of formula. Some of the same criteria can be applied to what are called graphic novels, a form encompassing both fact and fiction that relies on pictures (sometimes accompanied by text) to drive a narrative. ${ }^{10}$

Graphic novels tend to present provocative stories, both fiction and non-fiction, in a visually striking format. "Graphic novels as a format," asserts Ruth Boyer, "produce some of the most thoughtful and beautiful stories in the history of humankind." ${ }^{11} \mathrm{Li}$ braries, including public, school, and academic, are actively adding these materials to collections since patrons are eager to use these print resources.

\section{Graphic Novels in Academia}

College students enjoy reading graphic novels and professors are integrating them into their curricula. ${ }^{12}$ Academic libraries are adding graphic novels into their collections on account of this increasing attention. Graphic novels not only meet users' reading interests, but are useful in presenting historical and biographical topics. The advantages of using graphic novels in the curriculum have been well documented. ${ }^{13}$ Thomas Juneau and Mira Sucharov discussed the value of using graphic novels in college courses, stating that graphic novels reach students on both visual and intellectual levels that traditional texts lack. ${ }^{14}$ Elizabeth Downey wrote about the successful use of graphic novels to improve student comprehension, awareness of social issues, and ability to better interpret themes. ${ }^{15}$ Anne-Marie Davis

\section{The faculty reported that the use of graphic novels in their courses prompted engaged discussions among the students, including those that had previously been reluctant to enter into class conversations.} uses graphic novels to teach concepts of war, violence, and genocide. ${ }^{16}$ To further investigate the use of graphic novels in the classroom, Davis conducted a survey of University of Washington professors. The faculty reported that the use of graphic novels in their courses prompted engaged discussions among the students, including those that had previously been reluctant to enter into class conversations. Davis found that graphic novels were used in areas of study including art, anthropology, European history, cultural studies, and Japanese literature. Steven Hoover advocated for the use of graphic novels in academia "because graphic novels 
rely on the synthesis of textual and visual information to create meaning, their potential value is difficult to ignore." 17

As the use of graphic novels has increased, so has research into their merit. The focus of most of this research has been on the additional context graphic novels provide and their impact on student engagement in the classroom. ${ }^{18} \mathrm{~A}$ recent study by Janette Michelle Hughes et al. found that adolescents demonstrated an increased interest and excitement in writing assignments using graphic novels to improve reading. ${ }^{19}$ Val Bunn found that through the promotion of graphic novels, male teens were more likely to engage in additional reading. ${ }^{20}$ Paul Alexio and Claire Norris highlighted the value of comics and graphic novels in fostering reading. ${ }^{21}$

\section{Graphic Novels and Language}

As libraries find themselves adding graphic novels to collections, they must determine the best method for making these materials available to users. Graphic novels become a bit of a puzzle. Lorena O'English, J. Gregory Matthews, and Elizabeth Blakesley Lindsay noted that graphic novels have never quite fit in with other traditional formats. ${ }^{22}$ They are in one sense a novel that can be cataloged and shelved as any other literary work by author or as nonfiction book by subject; however, the visual nature of the novel sets it apart and gives it a unique usage. Some libraries have chosen another strategy by classifying the materials based on the visual nature, mixing them in with art resources.

The phrase graphic novel(s) is widely used both in natural language and in controlled vocabulary. For users to locate desired materials it is invaluable for finding aids to use familiar language. The literature suggests that social tagging can provide access points that complement traditional cataloging. ${ }^{23}$ With traditional cataloging alone, it is possible that materials that we have carefully selected and added to our collections can become "lost" because vocabulary common to users, but not part of the Library of Congress subject headings, is not included in the bibliographic record. From survey of campuswide faculty, Davis determined the term or phrase most often used by the faculty to describe a graphic novel was graphic novel. ${ }^{24}$ Only one faculty member preferred to use the term comics. Davis' study demonstrates the importance of having the "current" terms available in the online catalog. It should be anticipated that faculty and the students will expect to find material using the same terms they are hearing in their courses. These terms can be used in social tagging. However, social tagging needs to supplement, not replace cataloging.

\section{Social Media and Libraries}

\section{Discovery tools}

Social media has greatly changed user expectations, activities, and interest. While users' preferred social media tools may change, the appeal of the tools' shared environment and functionality remains consistent. To adapt to the changes, libraries are engaging staff and incorporating resources to keep up with users' interests. In a recent study, Laura Saunders surveyed academic reference librarians about their engagement with social media applications and found they were spending twenty percent of their time 
engaged in a variety of social media-related activities. ${ }^{25}$ The use of a discovery tool and the social tagging function is one of those adaptations. Discovery tools facilitate the end user interface with a corresponding search utility for retrieving, displaying, and interacting with the content in a library catalog system. ${ }^{26}$

Social tagging also offers academic libraries the opportunity to take advantage of the knowledge and expertise of the faculty, staff, and student populations on their campuses. For social tagging to be truly complementary to cataloging, there would need to be a vested interest among faculty, staff and students to contribute. Libraries would need to determine their users' awareness of social tagging in the discovery tools, interest, and barriers to creating tags. While sharing some similarities, discovery tools vary in structure and functionality. Previous studies that have focused on discovery tools have had little detail about social tagging at academic libraries. Birong Ho, Keith Kelley, and Scott Garrison reported on the implementation of VuFind at Western Michigan University Libraries and found little interest in social tagging at the time of their research. ${ }^{27}$ They felt that lack of interest in social tagging reflected the view of the online catalog as a non-social environment. It has been several years since that implementation, and discovery tools are more commonly found at academic libraries. It would be interesting to review the discovery layer to determine if there has been an increase in social tagging.

As discovery tools become more common, users' expectations about the interface of the online catalog will change as well. Academic libraries have the opportunity to draw upon the subject expertise of their users to develop social tags that enhance access to materials in the online catalog. To maximize the benefits, libraries could encourage and market these tools to further engage their faculty, staff, and students.

Paula Webb and Muriel Nero reviewed academic libraries' sites to evaluate social tagging in four different social tagging systems and discovery tools. ${ }^{28}$ They found that the discovery tools had varied degrees of ease of use and each required a certain degree of learning in order to search effectively. A discovery layer that requires a larger learning curve to use is a possible deterrent for the creation of social tags.

\section{Social tags}

Social tags are a means of identifying and retrieving digitized information. Social tagging allows users to identify terms and phrases for specific information sources. ${ }^{29}$ This Web 2.0 technology is used in many social media applications including Facebook, Flickr, and $\mathrm{HuLu}$, and provides a user-generated labeling on the Internet. Steele pointed out that shared vocabulary, or folksonomy, originates with the end user and offers a positive contribution to bibliographic records because by their very nature social tags reflect users' vocabulary or natural language in its current state. ${ }^{30}$ Some would argue that the social tags will be too personal and assigned without consideration of other users. ${ }^{31}$ However, when in 2010 Joyline Makani and Louise Spiteri conducted a study on social tagging for CiteUlike, a free service that allows users to store, organize, and share their favorite online resources, they found that CiteULike users tended to be selective about the social tags and frequently used social tags created by others. Makani and Spiteri posited that these behaviors were the establishment of a folksonomy within a specific site and suggested that the sense of community and personal contributions strengthen the intellectual authority 
of the added terms. ${ }^{32}$ The social tags for a specific resource, such as a discovery layer, can create a common vocabulary for a variety of user types. Susan Gibbons stated that tagging and the folksonomies op-

Tagging allows users to share information and identify it in such a way that other users, with similar tastes and agendas, can easily retrieve the resource. tions should be offered by libraries for access as well as for promoting users' research. ${ }^{33}$ The rapid growth of Web, electronic, and digital resources has created a new and challenging set of information to be searched, retrieved, and organized.

Tagging allows users to share information and identify it in such a way that other users, with similar tastes and agendas, can easily retrieve the resource.

\section{LCSH versus Tags}

For a long time, libraries have used Library of Congress subject headings (LCSH) to enhance retrievability for the end user. Some argue that Library of Congress classification can often be too rigid for end users. ${ }^{34}$ Several researchers have studied tagging relative to Library of Congress subject headings (LCSH) to determine patterns and collaborative strategies. These studies have focused on academic settings to compare the LCSH in the records with social tags found in LibraryThing. ${ }^{35}$

According to Marliese Thomas, Dana Caudle, and Cecilia Schmitz, social tagging can play an important role in enhancing the metadata in an online catalog by expanding the terminology available to users who conduct research. ${ }^{36}$ Their study examined tagging in academic and public online catalogs that use LibraryThing in seven libraries hosting a variety of discovery tools and tagging systems. The researchers evaluated over 8,000 social tags. The results indicated that more than half of the social tags reflected the topic of the representative work. They found only a small cross section of common terms between the social tag content and the assigned subject headings, and found that almost one third of the social tags represented valid subject headings but had not been included in the record. In another study, Constantia Kakali and Christos Papatheodorou researched the relationship between the use of social tags and subject headings in the online catalog at the Panteion University Library and reviewed over 500 social tags within over 200 bibliographic records. ${ }^{37}$ They determined that over ninety percent of the social tags enhanced the subject access of the records. Similar to other studies, they found that the social tags represented both broader and narrower terms than the LC subject headings. In some instances the authors felt that the social tags actually provided better descriptions of the content than the subject headings.

Svein Anfinnsen, Gheorghita Ghinea, and Sergio de Cesare reported that while the social tags may not make sense from librarians' perspective, they are relevant for a user's information retrieval purposes. ${ }^{38}$ These metadata are linked in ways that would not be possible with traditional cataloging alone. Scott Golder and Bernardo Huberman refer to this as "sensemaking." This concept focuses on the idea that taggers create metadata in relation to their own life experiences. ${ }^{39}$

Christine Dezelar-Tiedman compared a subset of the subject headings from the University of Minnesota's bibliographic records to the social tags for identical titles in 
LibraryThing. ${ }^{40}$ She found that more than half of the bibliographic records contained no subject headings; however, more than seventy percent of the same titles had social tags added to the records in LibraryThing. In these instances, the tagging done by users created additional access points for many records, with only a small number of records where the social tags and subject headings overlapped. More than fifty percent of the social tags represented topics not covered by subject headings. A review of the social tags revealed that in some instances, the tags provided a more precise and correct assessment of the material content than information offered in the bibliographic record. The creation of social tags to supplement subject headings can produce a richer set of metadata to help with describing the content of materials. This richness of metadata allows users to create highly specific and successful searches.

The strengths of social tags play to the weaknesses of subject analysis and indexing. ${ }^{41}$ Tagging does not require a high degree of maintenance, can provide currency in terminology, reflects research behaviors, and is relatively uncomplicated for the end user. Tagging and cataloging have similar outcome objectives, to create and maintain access to resources through the use of metadata. Used together, they can improve upon the rate of retrieval of materials within a library's discovery layer or online catalog.

Scott McFadden and Jenna Venker Weidenbenner contend that users think in natural language terminology and the manner in which they organize information is different than how it is organized in online catalog records. ${ }^{42}$ They further argue that by providing additional access points, librarians can have insight into users' interests in resources and how they think about identifying and accessing them. Lois Mai Chan affirms that by studying patterns

The strengths of social tags play to the weaknesses of subject analysis and indexing. of tagging behavior researchers and practitioners can gain insight into users' information retrieval strategies, which will influence the conceptual basis for cataloging practices and policies. ${ }^{43}$

Like social tags, the terminology in genre headings can provide increased access and discoverability of materials in online catalogs beyond what is provided by subject headings. The benefit of adding genre headings is not limited to literature. Carrie Newsom, Jimmie Lundgren, and Nancy Mitchell Poehlmann examined the existing subject terms applied to the resources in their library's online catalog and determined they were not meeting the research needs of the faculty and students in the chemistry and engineering programs at the University of Florida. ${ }^{44}$ To facilitate discoverability within their catalog, genre headings were added that included detailed phrases and terms specific to the fields of chemistry and engineering. Music is another subject area that benefits from the use of detailed and specific genre headings and terms. ${ }^{45}$ The Library of Congress Music Genre/Form Project Group has worked for several years to create a list of genre and form terms to improve access by including terminology and concepts to end users. For years, the value of having detailed form/genre headings for foreign language films has been discussed, with the benefit identified that users would be able to search by criteria specific to foreign films and achieve more precise search results. ${ }^{46}$ 


\section{Research Questions}

As noted above, tagging and LCSHs provide needed metadata for users to access resources. While studies have compared the two access utilities they have mainly focused on content for metadata purposes. This study will review resource format and access, in particular graphic novels. Questions include:

- Do academic libraries provide users with the option to add social tags within their online catalog or discovery layer?

- When libraries provide tagging capabilities do end users tag graphic novels to enhance access?

- Are there specific patterns in the tagging terminology of graphic novels (that is, use of the term graphic novels)?

- What metadata are catalogers using to identify graphic novels?

- Does retrospective tagging play a role in access enhancement of earlier issued graphic novels?

\section{Methods}

This study was initiated to address these questions and test the practices of cataloging and the engagement of social tagging of graphic novels. By searching in library catalogs and discovery tools, the research attempted to identify specific metadata patterns. The seventy-five libraries selected for this research are academic institutions from the ARL member list, and are also included on the American Library Association list of the largest libraries in the United States. ${ }^{47}$ ARL institutions fulfill rigorous criteria for membership and as such it would be expected that cataloging and tagging practices would meet a similar standard. ${ }^{48}$ The online catalogs and discovery tools of this set were reviewed to determine the availability of social tagging for users of these institutions. This review determined that 38 libraries (51 percent) offered users the option to tag records in either the online catalog or a discovery layer; the remaining 37 libraries (49 percent) did not. The 38 libraries with tagging options made up the study's sample libraries, all of which use Library of Congress classification (see Appendix B).

The level of tagging and cataloging was evaluated by comparing their holdings with a core list of graphic novels. In Eric Werthmann's study on graphic novel collections, the researcher used graphic novels which had received major awards in the comics' field. ${ }^{49}$ For this current study, the author chose a different approach, so as to include both popular (for example, Maus, Maus II) and less popular (for example, Amelia Earhart: This Broad Ocean ) graphic novels, which might influence tagging initiatives. The book titles selected for this project were retrieved from OCLC's WorldCat database from July through August 2011 using a series of searches constructed to isolate records for books that were graphic novels but, that lacked the phrase graphic novel in either the subject or genre headings. This would provide comparability for tagging. The list of titles that resulted from these searches generated slightly more than 300 results. All of the selections were physically reviewed using the criteria typically accepted for a graphic novel, in that it is a work of fiction or non-fiction presented in a sequential art form. After this review the sample was reduced to 59 titles (see Appendix C). 
Once the title list was created, the 59 graphic novel titles were searched in each of the 38 library collections to determine availability, whether the genre heading "graphic novels" appeared in the record, and if the records had been assigned graphic novel tags by users; information for each was documented for further analysis.

\section{Results and Discussion}

\section{Graphic Novels in the Study}

Of the 59 titles, 54 (91.5 percent) were in at least one collection of the sample libraries; five ( 8.5 percent) were in none of the libraries. The range for the holdings was zero ( 0 percent) libraries with the title to 32 libraries (84.2 percent) for the two Maus selections. Eleven (18.6 percent) of the titles were in at least fifty percent of the libraries (see Appendix A). The publication dates ranged from 1979 through 2010; there was one (1.7 percent) title from the1970s decade, two (3.4 percent) from the 1980s, eight (13.6 percent) from the1990s; 45 (76.2 percent) from the 2000s, and three (5.1 percent) from 2010 and on.

\section{Graphic Novels in Sample Libraries}

Results from the libraries' catalog searches indicate that graphic novels are being added to the collections. The searches for the selected graphic novel titles $(n=59)$ found that 668 graphic novels were cataloged in the 38 libraries, each of the study's libraries contained at least six (ten percent) of the titles; with two libraries containing a maximum of 36 (61 percent). A distribution of the number of titles owned by the libraries showed that four libraries (ten percent) owned between zero and nine titles; twenty (53 percent) had between ten and nineteen titles; twelve ( 32 percent) had between twenty and 29 titles; and two (5 percent) had between thirty and 39 titles (see Figure 1). The mean number of titles was 17.57 , with a standard deviation of 7.5 , and the median was sixteen titles.

\section{Discovery Tools}

The social tagging of graphic novels will expand access capabilities to end users. From a review of the study's libraries the functionality of user tags varied among discovery tools. All of the discovery tools clearly offered the user the ability to tag a record. (Note, one institution provided tagging at the start of the search, upon later review that capability had been discontinued). Thirteen (34 percent) offered users a search utility to retrieve tagged items. Seven (18.4 percent) offered users the ability to refine the results list with tag terms but did not offer the ability to search the social tag terms separately.

The inability to search catalogs using the tag metadata impedes the accessibility of the resources. For users to access graphic novels through a search, they first need to find at least one tagged graphic novel in order to link to others, rather than having a search function to retrieve the desired resources. In some discovery tools, there were tag clouds that the user could manipulate to select graphic novel and narrow their search needs. In these tools, the ability to refine a search required the user to first find a tagged graphic novel record in order to find similar records. In some instances, searching on the cloud format became problematic, because since the refinement of the linking mechanism was not limited to the user tag graphic novels, but to many other related terms (for example, 


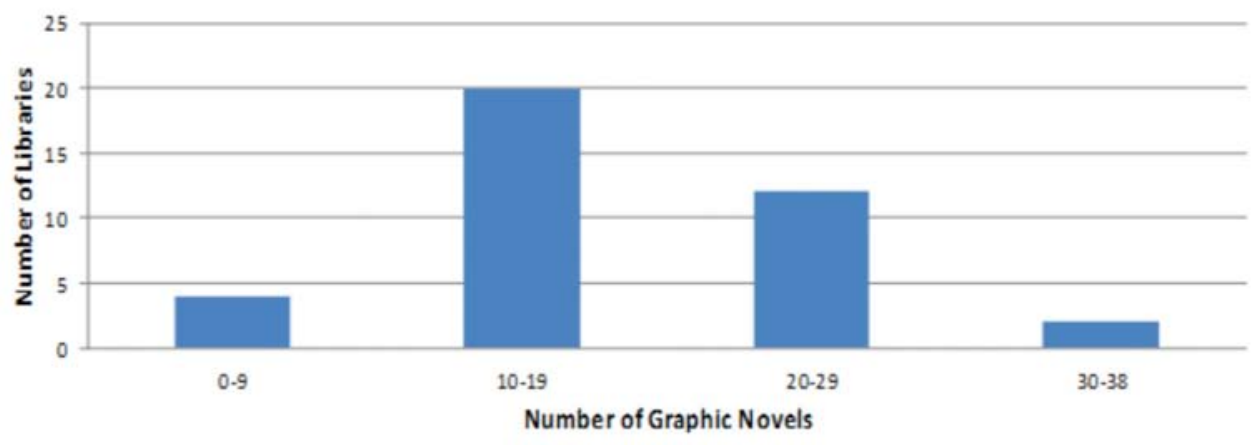

Figure 1. Libraries by Number of Graphic Novels in Collection

\section{Table 1}

\section{Number of Tagged Graphic Novels by Number of Libraries}

\begin{tabular}{|c|c|c|c|}
\hline & Tagged GNs & Number of Libraries & Total Tagged GNs \\
\hline & 0 & 19 & 0 \\
\hline & 1 & 3 & 3 \\
\hline & 2 & 3 & 6 \\
\hline & 3 & 4 & 12 \\
\hline & 4 & 2 & 8 \\
\hline & 5 & 1 & 5 \\
\hline & 6 & 3 & 18 \\
\hline & 11 & 1 & 11 \\
\hline & 12 & 1 & 12 \\
\hline & 24 & 1 & 24 \\
\hline Total & & 38 & 99 \\
\hline
\end{tabular}

graphic alone), it searched the entire record rather than just records with graphic novels; thus making the retrieval tool ineffective.

\section{Graphic novels and social tagging}

Search results of the study's 59 graphic novel titles in the 38 libraries' discovery tools or next generation catalogs for both social tagging activity and genre headings (655) designations indicated that there were 99 tagged graphic novel titles across the collections. The 


\section{Table 2}

\section{Number and Percent of Tagged Graphic Novels in Libraries with Tagged Items}

\begin{tabular}{ccc}
\hline Number GNS & Number GNs Tagged & Percent Tagged \\
\hline 10 & 1 & $10.00 \%$ \\
17 & 1 & $6.00 \%$ \\
23 & 1 & $4.00 \%$ \\
9 & 2 & $22.00 \%$ \\
13 & 2 & $15.00 \%$ \\
14 & 2 & $14.00 \%$ \\
14 & 3 & $21.00 \%$ \\
16 & 3 & $19.00 \%$ \\
17 & 3 & $18.00 \%$ \\
18 & 3 & $17.00 \%$ \\
15 & 4 & $27.00 \%$ \\
20 & 4 & $20.00 \%$ \\
23 & 5 & $22.00 \%$ \\
29 & 6 & $21.00 \%$ \\
36 & 6 & $17.00 \%$ \\
36 & 6 & $17.00 \%$ \\
11 & 11 & $100.00 \%$ \\
16 & 12 & $75.00 \%$ \\
24 & 24 & $100.00 \%$ \\
\hline
\end{tabular}

results of tagging activity showed that nineteen (fifty percent) libraries did not contain tags and the remaining nineteen (fifty percent) libraries had at least one graphic novel that had been tagged with that indication. The layout in Table 1 provides the breakdown of the number of graphic novels tagged by the number of libraries. Two (5.2 percent) of the 38 libraries introduced tags using LibraryThing. These two libraries had 100 percent of their graphic novels tagged. This may not reflect local tagging behavior since these tags may have been created by a larger pool of users. While LibraryThing and other tagging tools offer the possibility of increased tagging activity, it may not necessarily be relevant for the target users at the local level.

A closer analysis of the libraries that had graphic novel tagging activity $(n=19)$ indicated that only a small percentage of the libraries' titles were tagged. Sixteen (84 percent) of the libraries had tagged less than 22 percent of their graphic novel titles. Three (16 percent) of the libraries had one library with 75 percent of its titles tagged and two libraries had 100 percent of the graphic novel titles tagged (see Table 2). 


\section{Graphic Novels and Cataloging Practices}

The results found limited access to the sample titles using the phrase graphic novels. Of the 668 graphic novel records, 64 (9.6 percent) had titles with the phrase graphic novels in the genre heading. Further analysis of those 64 records showed that 39 (60.9 percent) records had been updated in WorldCat and include the genre heading "graphic novels." There were 21 records (32.8 percent) containing the genre heading "graphic novels" added at the local level. The origination of the genre heading placed in the remaining four (6.3 percent) records was not identifiable.

A review of the sample libraries $(n=38)$ found that 28 (73.7 percent) had at least one graphic novel record updated with an identifying genre heading. Of the 28 libraries that had the genre heading "graphic novels," fifteen (53.5 percent) had used this identifier in less than ten percent of the sample graphic novels; eight libraries (28.5 percent) had used it between 10.1 percent and twenty percent of the time; and the remaining five (17.9 percent) had between 21.4 percent and 43.4 percent of their sample titles cataloged with the genre heading "graphic novels" (see Table 3).

\section{Accessibility of Graphic Novels using Genre Heading or Tagging}

A review of the records was initiated to determine accessibility rates of the sample titles via genre heading or tagging options. Only 143 (21.4 percent) of the sample titles had access either through the genre headings in the bibliographic records or were tagged. Ninety-nine (14.8 percent) of the titles had graphic novel tags added and 68 (10.2 percent) contained genre headings. There was an overlap of twenty (3.0 percent) titles that had both the genre heading and a graphic novel tag. The social tags offered slightly more added access than was offered in the bibliographic records alone. Very little duplication of effort, suggests that increased tagging was beneficial to access.

Traditionally, once a title has been added to an online catalog it is unlikely that the record would be altered unless a specific request was made. Social tags provide a mechanism to enhance records and access of older works. This is reflected in the titles used in this study. For the sample's 28 titles published between 1979 and 2003, there were 393 (58.8 percent) bibliographic records. For those titles, there were twice as many instances of graphic novel tags (56), than genre headings (24). For the 28 titles published between 2005 and 2010, there was little variation between the tagging and cataloging practices. Of the 280 (41.9 percent) bibliographic records, forty (14.2 percent) had graphic novel tags and 44 (15.7 percent) had been cataloged with the genre heading. There was a slightly larger overlap of five percent containing both genre headings and tags. Compared to the 1979-2003 title set, these records contained a higher percentage of genre headings (10.2 percent vs. 15.7 percent) and comparable percentage of tagging activity (14.8 percent to 14.2 percent).

\section{Limitations}

The identification of "graphic novels" as a genre heading remains controversial. Many cataloging practitioners argue that graphic novels are a format rather than a genre, while others have advocated for the term's use as a genre heading to improve access. ${ }^{50}$ The interest of this study focused on the accessing of graphic novels, and, as such, the use of 


\section{Table 3}

Number and Percent of Tagged Graphic Novels with Corresponding Genre Headings in Libraries with Genre Headings Libraries

\begin{tabular}{lcc}
\hline Number GNS & $\begin{array}{c}\text { Number with GN } \\
\text { Genre Heading }\end{array}$ & $\begin{array}{c}\text { Percent with GN } \\
\text { Genre Heading }\end{array}$ \\
\hline
\end{tabular}

7

11

12

13

16

20

26

28

13

17

15

20

29

10

14

16

18

23

36

24

28

17

9

14

36

11

22

23
$14.20 \%$

$9.00 \%$

$8.30 \%$

$7.70 \%$

$6.30 \%$

$5.00 \%$

$3.80 \%$

$3.60 \%$

$7.70 \%$

$5.80 \%$

$6.70 \%$

$5.00 \%$

$3.40 \%$

$20.00 \%$

$14.20 \%$

$12.50 \%$

$11.10 \%$

$8.70 \%$

$5.50 \%$

$8.30 \%$

$10.70 \%$

$17.60 \%$

$33.30 \%$

$21.40 \%$

$11.10 \%$

$45.40 \%$

$27.20 \%$

$43.40 \%$ 
this term in the genre heading of a record. Since catalogers have different opinions about cataloging graphic novels, one would expect variations in the results. The researcher did not conduct a survey of the sample libraries to determine these differing philosophies, so a correlation between the two cannot be determined.

Graphic novels are a unique resource and the practice of adding these materials to collections varied among the study's academic libraries. There was a wide range of holdings, which impacted the number of potential tagging opportunities across the libraries.

\section{Conclusions}

The results of this study indicate that while social tags and/or genre headings did provide additional access to graphic novels, their use is limited across the study's library population. Goldsmith points out that if graphic novels are not separated out physically, and are classified the same as other works, they will be difficult for users to locate. ${ }^{51}$ Michael Pawuk cautions librarians that, while there are different approaches to cataloging graphic novels, these materials need to be easily distinguishable from others within the library's collections. ${ }^{52}$ Happily, the addition of the genre heading (655) and social tagging increases the potential for users to identify and locate the materials. Given the high costs of cataloging, batch loading of records, and reductions in staffing among libraries, it would be advantageous to add genre headings at the point of record origination or facilitate tagging.

Genre headings can be added after cataloging has originally taken place, however, locating graphic novels after-the-fact can be challenging. This is especially true for libraries that have integrated graphic novels into their collections based on the content. An example of this practice of adding genre headings at a later date occurred at the University at Albany Libraries. Cataloging Services conducted a project to identify graphic novels within the collections and add genre headings (655 tag) to their records. Graphic novel titles are distributed throughout the collections and have been assigned a variety of classification numbers due to the varying subjects. The records were retrieved using a series of subject and keyword searches using the terminology or phrase graphic novels. This approach retrieved not only graphic novel titles but also materials about graphic novels. It also failed to retrieve records that did not have subject headings or notes that included those search terms. Later, after completion of the project to add genre headings to the records, it became evident that the attempts to identify the records for graphic novel titles were not entirely successful. Several graphic novel titles without genre headings were found in the collections through serendipitous discovery. The difficulty catalogers had in trying to identify graphic novel titles within the online catalog speaks to the difficulties users experience with locating similar material types.

Review of the records for the titles that were updated to include genre headings revealed an increase in circulation for some of the titles. A subject search retrieved 97 records for graphic novels. Forty-two of those titles (43 percent) had no circulation history recorded. The remaining 55 titles (57 percent) had varying degrees of circulation after the addition of the genre headings. Eight of the titles (15 percent) showed no additional circulation. The remaining titles showed varying degrees of circulation that ranged from one to fifteen additional loans. 


\section{Table 4}

\section{Loans Occuring After AddingGraphic Novel Genre Headings (655s) to Catalog Records}

\begin{tabular}{cccc}
\hline Number of Records & Percentage of titles & Additional loans \\
\hline & & $22 \%$ & 1 \\
12 & $20 \%$ & 3 \\
& & $15 \%$ & 4 \\
& 8 & $15 \%$ & 0 \\
& 6 & $11 \%$ & 2 \\
& 6 & $11 \%$ & 5 to 7 \\
& 3 & $5 \%$ & 8 \\
& 1 & $2 \%$ & \\
& & & \\
\hline
\end{tabular}

While it cannot be determined from this data that the addition of genre headings contributed to the increased circulation, it points to an interesting topic for future research with this collection.

The benefits of libraries including social tags in their discovery tools are obvious. How frequently do we find ourselves explaining to a user that the key to finding the resources they want in our collection hinge on finding the correct terminology to search for these materials? Should a user need to regularly open the Library of Congress Subject Headings to determine if they are using the correct terms; or hunt in the catalog until they find a record with the subject heading that they need? It is highly unlikely that most users think about searching in that manner. Social tagging provides a provocative mechanism for user access. Libraries need to provide adequate search mechanisms to promote effective retrieval.

The benefits of allowing social tagging in our catalogs and discovery interfaces are clear, given the potential pool of engaged users and resident experts on campus who will enhance records through this process. Most libraries cannot afford to hire catalogers to cover every area of research proficiently. Having the expertise of highly specialized researchers to identify and provide additional access to resources is invaluable.

Genre headings providing more intuitive terminology can be added to bibliographic records to offer an additional access point in the online catalog, when indexed. The review of the libraries' discovery tools and online catalogs determined that the majority of records, 604 (90.4 percent) contained no genre headings with the graphic novel term. By changing cataloging practice and adding this term into the heading, end users will have a stronger possibility of retrieving these materials. 


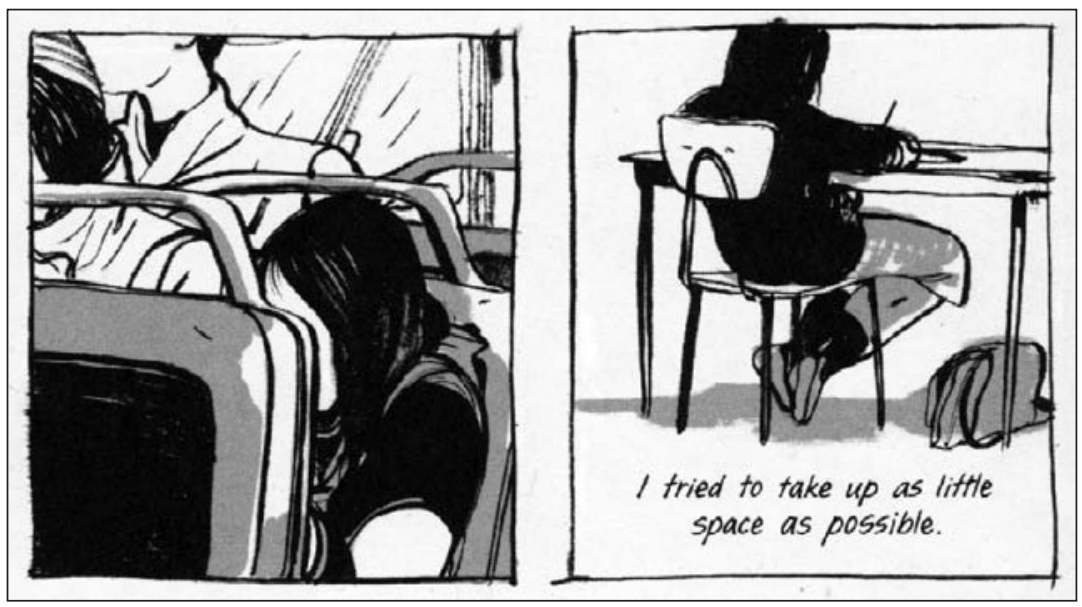

Figure 2. Panels from graphic novel. Reprinted with permission from Mariko Tamaki and Jillian Tamaki, Skim. (Toronto, Groundwood Books, 2008),105.

Some libraries advocate for other methods of making graphic novels accessible, such as giving some of the titles unique call numbers, adding graphic novel information to note fields, and / or designating special physical locations to set them apart from the rest of the collection, but this is not always helpful in large academic libraries.

The aim of this research was to identify in specific academic libraries current trends in the accessibility of graphic novels, with a focus on tagging and on cataloging with the use of genre headings. The results found that there are gaps in these practices, thus limiting the access of graphic novels. The author proposes a discussion of changes in cataloging practices, as well as the promotion of social tagging tools in the next generation catalogs to enhance record access.

Additional research should focus on academic library users and what motivates them to tag, and include qualitative research for the reasons for tagging/not tagging, and explore techniques for encouraging users to tag materials and bring in added value to our metadata. A review of a wider range of social tags at academic libraries could help identify areas of interest among users and methods of categorization that may deviate from the classification given by catalogers. Having a direct view of how users are researching can assist libraries in making decisions about services, cataloging, and collection building.

Wendy West is Head of the Database Maintenance, Processing, and Bindery Department at University at Albany, e-mail: wwest@albany.edu. 


\section{Appendix A: Graphic Novels and Holdings Counts}

\begin{tabular}{ccc}
\hline Title & Library & Percent Holdings \\
& Holdings & with Title \\
\hline
\end{tabular}

Maus II : a survivor's tale : and 32

84.2

here my troubles began

Maus : a survivor's tale $\quad 32$

84.2

Understanding comics : the invisible art

78.9

beats : a graphic history

76.3

Palestine

71.1

Safe area Gorazde

63.2

David Boring

60.5

people's history of American empire :

55.3

a graphic adaptation

Cancer vixen : a true story

52.6

Breakdowns : portrait of the artist as a

young\%@[squiggle][star]!

Watchmen book club ed.

Freud for beginners

Pedro and me : friendship, loss, and

what I learned

Ethel \& Ernest

Malcolm X : a graphic biography

Watchmen

Deogratias, a tale of Rwanda

31.6

American widow

Kingdom come

Stinky : a toon book

It was a dark and silly night ...

magical life of Long Tack Sam

Thoreau at Walden

Sandman : doll's house 
Appendix A. Continued.

\begin{tabular}{lcc}
\hline Title & Library & Percent Holdings \\
& Holdings & with Title \\
\hline
\end{tabular}

Fallout : J. Robert Oppenheimer, Leo Szilard, 8

and the political science of the atomic bomb

$\begin{array}{ll}\text { books of magic } & 7\end{array}$

Pitch black

Clan Apis

Amelia Earhart free in the skies

Jack and the box : a toon book

Adventures of Tintin

Captain Underpants extra-crunchy book o' fun

Fray

Lindbergh child

Silly Lilly and the four seasons : a toon book

Power \& responsibility

Around the world

Charles Darwin's On the origin of species :

a graphic adaptation

Amelia Earhart : this broad ocean

last knight : an introduction to Don Quixote by

Miquel de Cervantes

Into the air : the story of the Wright

brothers' first flight

Vögelein : clockwork faerie

No girls allowed : tales of daring women dressed as men for love, freedom and adventure

Mercury

Ghost circles

Hercules : the twelve labors

invisible man

Emperor of the airwaves

revenge of Clayface

Buzz Boy and Fly Guy

Superman, Batman. Public enemies 0

dream thief 
Appendix A. Continued.

\begin{tabular}{lcc}
\hline Title & Library & Percent Holdings \\
& Holdings & with Title \\
\hline
\end{tabular}

Solving crimes with trace evidence

0

0

Last son of Krypton

0

0

monstruo del Lago Ness : una misteriosa

0

0

\section{Appendix B: List of Graphic Novel Titles}

\section{Title}

1. Adventures of Tintin

2. Amelia Earhart : this broad ocean

3. Amelia Earhart free in the skies

4. American widow

5. Around the world

6. beats : a graphic history

7. books of magic

8. Breakdowns : portrait of the artist as a young \%@[squiggle][star]!

9. Buzz Boy and Fly Guy

10. Cancer vixen : a true story

11. Captain Underpants extra-crunchy book o' fun

12. Charles Darwin's On the origin of species : a graphic adaptation

13. Clan Apis

14. David Boring

15. Deogratias, a tale of Rwanda

16. dream thief

17. Emperor of the airwaves

18. Ethel \& Ernest

19. Fagin the Jew

20. Fallout : J. Robert Oppenheimer, Leo Szilard, and the political science of the atomic bomb

21. Folklore \& fairy tale funnies (little lit: folklore...)

22. Fray

23. Freud for beginners

24. Ghost circles

25. Hercules : the twelve labors

26. Into the air : the story of the Wright brothers' first flight
Date

[1993]

2010

2003

2008

2005

2009

1993

2008

2010

2006

2001

2009

2000

2000

2006

2006

2009

1999

2003

2001

2000

2003

1979

2001

2007

2002 
Appendix B. Continued.

\begin{tabular}{|c|c|c|}
\hline Titl & & Date \\
\hline 27. & invisible man & 2008 \\
\hline & It was a dark and silly night ... & 2003 \\
\hline & Jack and the box : a toon book & 2008 \\
\hline & Kingdom come & 1997 \\
\hline & last knight : an introduction to Don Quixote by Miquel de Cervantes & 2000 \\
\hline & Last son of Krypton & 2009 \\
\hline & Lindbergh child & 2008 \\
\hline & magical life of Long Tack Sam & 2007 \\
\hline & Malcolm $X$ : a graphic biography & 2006 \\
\hline & Maus : a survivor's tale & 1986 \\
\hline & Maus II : a survivor's tale : and here my troubles began & 1991 \\
\hline & Mercury & 2010 \\
\hline & monstruo del Lago Ness : una misteriosa bestia en Escocia & 2009 \\
\hline & No girls allowed : tales of daring women dressed as men for & 2008 \\
\hline & love, freedom and adventure & \\
\hline & Palestine & 2001 \\
\hline & Pedro and me : friendship, loss, and what I learned & 2000 \\
\hline & people's history of American empire : a graphic adaptation & 2008 \\
\hline & Pitch black & 2008 \\
\hline & Power \& responsibility & 2001 \\
\hline & revenge of Clayface & 2009 \\
\hline & Safe area Gorazde & 2000 \\
\hline & Sandman : doll's house & 1995 \\
\hline & Sandman : wake & 1997 \\
\hline & Silly Lilly and the four seasons : a toon book & 2008 \\
\hline 51. & Skim & 2008 \\
\hline & Solving crimes with trace evidence & 2008 \\
\hline & Stinky : a toon book & 2008 \\
\hline 54. & Superman, Batman. Public enemies & 2004 \\
\hline & Thoreau at Walden & 2008 \\
\hline & Understanding comics : the invisible art & 1994 \\
\hline & Vögelein : clockwork faerie & 2003 \\
\hline 58. & Watchmen & [2005] \\
\hline 59. & Watchmen book club ed. & 1987 \\
\hline
\end{tabular}




\section{Appendix C: ARL Libraries}

1. Arizona State University

2. Auburn University

3. Brigham Young University

4. Brown University

5. Columbia University

6. Cornell University

7. Duke University

8. Emory University

9. Florida State University

10. Georgetown University

11. Harvard University

12. Indiana University

13. Johns Hopkins University

14. Louisiana State University

15. Massachusetts Institute of Technology

16. Michigan State University

17. New York University

18. North Carolina State University

19. Northwestern University

20. Ohio State University

21. Pennsylvania State University

22. Princeton University

23. Rutgers University

24. Southern Illinois University - Carbondale

25. Stanford University

26. State University of New York - Buffalo

27. Syracuse University

28. Temple University

29. Texas A\&M University

30. Tulane University

31. University of Alabama

32. University of Arizona

33. University of California - Berkeley

34. University of California - Davis

35. University of California - Irvine

36. University of California - Los Angeles

37. University of California - San Diego

38. University of Chicago
39. University of Cincinnati

40. University of Colorado

41. University of Connecticut

42. University of Florida

43. University of Georgia

44. University of Hawaii

45. University of Illinois - Urbana-Champaign

46. University of Iowa

47. University of Kansas

48. University of Kentucky

49. University of Maryland

50. University of Massachusetts - Amherst

51. University of Miami

52. University of Michigan

53. University of Minnesota

54. University of Missouri - Columbia

55. University of Nebraska - Lincoln

56. University of New Mexico

57. University of North Carolina - Chapel Hill

58. University of Notre Dame

59. University of Oklahoma

60. University of Oregon Libraries

61. University of Pennsylvania

62. University of Pittsburgh

63. University of Rochester

64. University of South Carolina

65. University of Southern California

66. University of Tennessee - Knoxville

67. University of Texas - Austin

68. University of Utah

69. University of Virginia

70. University of Washington

71. University of Wisconsin - Madison

72. Vanderbilt University

73. Washington University - St. Louis

74. Wayne State University

75. Yale University 


\section{Notes}

1. Charlotte Cubbage, "Selection and Popular Culture in Large Academic Libraries: Taking the Temperature of Your Research Community," in Graphic Novels and Comics in Libraries and Archives, ed. Robert G. Weiner (Jefferson, NC: McFarland, 2010), 72-80; Amy Kiste Nyberg, "How Librarians Learned to Love the Graphic Novel," in Weiner, Graphic Novels, 35-37; Eric Werthmann, "Graphic Novel Holdings in Academic Libraries," in Weiner, Graphic Novels, 242-259; Steven Hoover, "The Case for Graphic Novels," Communications in Information Literacy 5, 2 (2011): 174-186.

2. Melissa Adler, "Transcending Library Catalogs: A Comparative Study of Controlled Terms in Library of Congress Subject Headings and User-Generated Tags in LibraryThing for Transgender Books," Journal of Web Librarianship 3, 4 (2009): 309-331, doi:10.1080 / 19322900903341099 (accessed October 31, 2012); Christine DeZelar-Tiedman, “Exploring User-Contributed Metadata's Potential to Enhance Access to Literary Works: Social Tagging in Academic Library Catalogs," Library Resources \& Technical Services 55, 4 (2011): 221-233; Karen G. Lawson, “Mining Social Tagging Data for Enhanced Subject Access for Readers and Researchers," Journal Of Academic Librarianship 35, 6 (2009): 574-582; Caimei Lu, Jung-ran Park, and Xiaohua Hu, "User Tags Versus Expert-Assigned Subject Terms: A Comparison of LibraryThing Tags and Library of Congress Subject Headings," Journal of Information Science 36, 6 (2010): 763-779, doi:10.1177/ 0165551510386173 (accessed October 31, 2012); Luiz H. Mendes, Jennie Quiñonez-Skinner, and Danielle Skaggs, "Subjecting the Catalog to Tagging," Library Hi Tech 27, 1 (2009): 30-41; Marliese Thomas, Dana M. Caudle, and Cecilia M. Schmitz, "To Tag or Not to Tag?," Library Hi Tech 27, 3 (2009): 411-434; Henk Voorbij, "The Value of LibraryThing Tags for Academic Libraries," Online Information Review 36, 2 (2012): 196-217, doi:10.1108/14684521211229039 (accessed October 31, 2012).

3. Susan Gibbons, The Academic Library and the Net Gen Student: Making the Connections. (Chicago: American Library Association, 2007) 67.

4. Amanda Stegall-Armour, "The Only Thing Graphic is Your Mind: Reconstructing the Reference Librarian's View of the Genre," in Weiner, Graphic Novels, 177-184.

5. Catherine Labio, "What's in a Name? The Academic Study of Comics and the 'Graphic Novel,"' Cinema Journal 50, 3 (2011): 123-126, doi: 10.1353/cj.2011.0033 (accessed October 31, 2012).

6. Eddie Campbell, “What is a Graphic Novel?," World Literature Today 81, 2 (2007): 13.

7. James Bucky Carter, "Literacy 2.0 Special Topic / Going Graphic," Educational Leadership 66, 6 (March 2009): 68-73, http://www.ascd.org/publications/educational-leadership/mar09/vol66/ num06/Going-Graphic.aspx (accessed March 28, 2013).

8. "Graphic," in Oxford English Dictionary Additions Series, Vol. 2, ed. John A. Simpson and Edmund S.C. Weiner (Oxford: Clarendon Press, 1993) 124.

9. Sid Jacobson, "After the Graphic Novel," New Leader 90, 3/4 (2007): 45-46, http://www. thenewleader.com/back-issues (accessed March 31, 2013).

10. Francisca Goldsmith, "Graphic Novels as Literature," Booklist 99, 11 (2003): 986.

11. Ruth Boyer, "Graphic Novels and the Untapped Audience," in Weiner, Graphic Novels, 141-144.

12. Werthmann, "Graphic Novel Holdings," 243-244; Lorena O'English, J. Gregory Matthews, and Elizabeth Blakesley Lindsay, "Graphic Novels in Academic Libraries: From Maus to Manga and Beyond," Journal of Academic Librarianship 32, 2 (2006): 173-182; Judith Rosen, "Children's Books Taking College Campuses by Storm," Publishers Weekly 259, 29 (July 16, 2012): 18-20; Mark Sanders, "Popular Reading Collections in Public University Libraries: A Survey of Three Southeastern States," Public Services Quarterly 5, 3 (2009): 174-183, doi:10.1080/15228950902976083 (accessed October 31, 2012).

13. Anne-Marie Davis, "Maus Goes to College," in Weiner, Graphic Novels, 81-86; Alicia C. Decker and Mauricio Castro, "Teaching History with Comic Books: A Case Study of 
Violence, War, and the Graphic Novel," History Teacher 45, 2 (2012): 169-188; Elizabeth M. Downey, "Graphic Novels in Curriculum and Instruction Collections, "Reference E User Services Quarterly 49, 2 (2009): 181-188; Hoover, “The Case for Graphic Novels," 177-178; Thomas Juneau and Mira Sucharov, "Narratives in Pencil: Using Graphic Novels to Teach Israeli-Palestinian Relations," International Studies Perspectives 11, 2 (2010): 172-183; O'English, Matthews, and Lindsay, "Graphic Novels in Academic Libraries," 178-179; Gretchen Schwarz, "Media Literacy, Graphic Novels, and Social Issues," Simile 7, 4 (2007): $1-11$.

14. Juneau and Sucharov, "Narratives in Pencil," 179.

15. Downey, "Graphic Novels in Curriculum," 181.

16. Davis, "Maus Goes to College," 81.

17. Hoover, "The Case for Graphic Novels," 179.

18. Val Bunn, "Researching the Tintin effect," School Librarian 60, 2 (2012): 74-76.

19. Janette Michelle Hughes et al., "Adolescents and 'Autographics': Reading and Writing Coming-of-Age Graphic Novels," Journal of Adolescent \& Adult Literacy 54, 8 (2011): 601-612, doi:10.1598/JAAL.54.8.5 (accessed October 31, 2012).

20. Bunn, "Researching the Tintin Effect," 75-76.

21. Paul Aleixo and Claire Norris, "Comics, Reading, and Primary Aged Children," Education $\mathcal{E}$ Health 25, 4 (2007): 70-73, http://sheu.org.uk/content/comics-reading-and-primary-agedchildren (accessed March 28, 2013).

22. O'English, Matthews, and Lindsay, "Graphic Novels in Academic Libraries," 178.

23. Gibbons, "Academic Library and the Net Gen Student," 73-74; Scott McFadden and Jenna Venker Weidenbenner, "Collaborative Tagging: Traditional Cataloging Meets the 'Wisdom of Crowds,'" Serials Librarian 58, 1-4 (2010): 55-60, doi:10.1080/ 03615261003623021 (accessed October 31, 2012).; Mendes, Quiñonez-Skinner, and Skaggs, "Subjecting the Catalog to Tagging," 39; Tom Steele, "The New Cooperative Cataloging," Library Hi Tech 27, 1 (2009): 68-77, doi.org/10.1108/07378830910942928 (accessed October 31, 2012); Voorbij, "Value of LibraryThing Tags," 215; Paula L. Webb and Muriel D. Nero, "OPACs in the Clouds," Computers in Libraries 29, 9 (2009): 18-22.

24. Davis, "Maus Goes to College," 82.

25. Laura Saunders, "The Reality of Reference: Responsibilities and Competencies for Current Reference Librarians," Public Services Quarterly 8, 2 (2012): 114-129.

26. Athena Hoeppner, "The Ins and Outs of Evaluating Web-Scale Discovery Services," Computers in Libraries 32, 3 (2012): 6-40, http://www.infotoday.com/cilmag/apr12/Hoeppner-WebScale-Discovery-Services.shtml (accessed March 28, 2013).

27. Birong Ho, Keith Kelley, and Scott Garrison, "Implementing VuFind as an Alternative to Voyager's Web Voyage Interface: One Library's Experience," Library Hi Tech 27, 1 (2009): 82-92, doi.org/10.1108/07378830910942946 (accessed October 31, 2012).

28. Webb and Nero, "OPACs in the Clouds," 22.

29. Ellen Daly and Neil Ballantyne, "Ensuring the Discoverability of Digital Images for Social Work Education: An Online 'Tagging' Survey to Test Controlled Vocabularies," Webology 6, 2 (2009): 1-16, http://www.webology.org/2009/v6n2/a69.html (accessed March 28, 2013).

30. Steele, “New Cooperative Cataloging," 70.

31. Scott A. Golder and Bernardo A. Huberman, "Usage Patterns of Collaborative Tagging Systems," Journal of Information Science 32, 2 (2006): 198-208, doi:10.1177/016555150606062337 (accessed October 31, 2012).

32. Joyline Makani, and Louise Spiteri, "The Dynamics of Collaborative Tagging: An Analysis of Tag Vocabulary Application in Knowledge Representation, Discovery, and Retrieval," Journal of Information E Knowledge Management 9, 2 (2010) 93-103, doi: 10.1142/ S0219649210002553 (accessed October 31, 2012).

33. Gibbons, "Academic Library and the Net Gen Student," 72.

34. Svein Anfinnsen, Gheorghita Ghinea, and Sergio de Cesare, "Web 2.0 and Folksonomies in a Library Context," International Journal of Information Management 31, 1 (2011): 63-70, doi. org / 10.1016/j.ijinfomgt.2010.05.006 (accessed October 31, 2012). 
35. Lu, Park, and Hu, "User Tags," 768-769; Elaine Peterson, "Patron Preferences for Folksonomy Tags: Research Findings When Both Hierarchical Subject Headings and Folksonomy Tags are Used," Evidence Based Library \& Information Practice 4, 1 (2009): 53-56, http://ejournals.library.ualberta.ca/index.php/EBLIP/article/view/4580/5081 (accessed October 31, 2012); Steele, "New Cooperative Cataloging," 73; Thomas, Caudle, and Schmitz, "To Tag or Not to Tag?," 416; Kwan Yi and Lois Mai Chan, "Linking Folksonomy to Library of Congress Subject Headings: An Exploratory Study," Journal of Documentation 65, 6 (2009): 872-900, doi: 10.1108/00220410910998906 (accessed October 31, 2012).

36. Thomas, Caudle, and Schmitz, "To Tag or Not to Tag?," 425.

37. Constantia Kakali and Christos Papatheodorou, "Exploitation of Folksonomies in Subject Analysis," Library E Information Science Research 32, 3 (2010): 192-202, doi.org/10.1016/j. lisr.2010.04.001 (accessed October 31, 2012).

38. Anfinnsen, Ghinea, and Cesare, "Web 2.0," 69.

39. Golder and Huberman, "Usage Patterns," 200-201.

40. DeZelar-Tiedman, "Exploring User-Contributed Metadata's Potential," 225-227.

41. Lois Mai Chan, "Social Bookmarking and Subject Indexing" in Subject Access: Preparing for the Future, ed. Patrice Landry et al. (Berlin: Walter de Gruyter, 2011), 127-142.

42. McFadden and Weidenbenner, "Collaborative Tagging," 58-59.

43. Chan, "Social Bookmarking," 134.

44. Carrie Newsom, Jimmie Lundgren, and Nancy Mitchell Poehlmann, "Genre Terms for Chemistry and Engineering: Not Just for Literature Anymore," Cataloging E Classification Quarterly 46, 4 (2008): 412-424, doi: 10.1080/01639370802323190 (accessed January 7, 2013).

45. Mark McKnight, "Are We There Yet?: Toward a Workable Controlled Vocabulary for Music," Fontes Artis Musicae 59, 3 (2012): 286-292.

46. Jeannette Ho, "Applying Form/Genre Headings to Foreign Films: A Summary of AUTOCAT and OLAC-LIST Discussions," Cataloging E Classification Quarterly 40, 2 (2005): 73-88, doi: 10.1300/J104v40n02_06 (accessed September 12, 2012).

47. Association of Research Libraries (ARL), Membership, "Member Libraries," (November 22, 2010), http://www.arl.org/arl/membership/members.shtml (accessed May 6, 2011); American Library Association, "ALA Library Fact Sheet 22 - The Nation's Largest Libraries: A Listing By Volumes Held," (July 2010), http://www.ala.org/ala/professionalresources/libfactsheets/ alalibraryfactsheet22.cfm (accessed May 6, 2011).

48. Karen Coyle, "Data, Raw and Cooked," Journal of Academic Librarianship 33, 5 (2007): 602-603; Martha Kyrillidou, "Research Library Trends: ARL Statistics," Journal of Academic Librarianship 26, 6 (2000): 427-436; Werthmann, "Graphic Novel Holdings," 246.

49. Werthmann, "Graphic Novel Holdings," 247-248.

50. Boyer, "Graphic Novels and the Untapped Audience," 141-142; Carter, "Going Graphic," 69; Stegall-Armour, "Only Thing Graphic is Your Mind," 178; Scott McCloud, Understanding Comics: The Invisible Art, (New York : HarperPerennial, 1994), 170; Francisca Goldsmith, Graphic Novels Now: Building, Managing, and Marketing a Dynamic Collection (Chicago: American Library Association, 2005), 53-55; O’English, Matthews, and Lindsay, "Graphic Novels in Academic Libraries," 174.

51. Goldsmith, Graphic Novels Now, 54-55.

52. Michael Pawuk, Graphic Novels: A Genre Guide to Comic Books, Manga, and More. (Westport, CT: Libraries Unlimited, 2007), xxiv. 